\title{
Legal certainty in taxation at authorities and courts of law: a nordic view of specialization and unbiasedness ${ }^{* *}$
}

DOI 10.1515/ntaxj-2016-0001

Received Oct 19, 2015; accepted Mar 13, 2016

\begin{abstract}
Legal certainty is central to taxation decisions. This article describes the current legal situation and discussions in four Nordic countries. Sweden and Finland are specialized in dealing with taxation cases in administrative courts. In Denmark and Norway, no specialization exists in taxation cases. I maintain in this article that legal certainty would benefit from explicit signals from the state about the requirement of special knowledge and unbiasedness in authority and court decisions. These signals could well take the form of specialization in the courts. The need for specialized expertise is particularly extensive in tax law. It is also crucial for the agencies' officials and judges to be aware that a subjective sense of unbiasedness in decision making does not necessarily mean that the unbiasedness aimed for has been attained. Self-awareness of this kind would ensure that argumentation and grounds for decisions would be made credible and transparent, to the benefit of legal certainty.
\end{abstract}

Keywords: tax; legal certainty; the Nordic countries; tax authorities; court; specialization; unbiasedness

\section{Introduction}

On March 6 and 7, 2015, a symposium was held in Århus, Denmark, in order to elucidate and discuss issues relating to taxation procedures in the Nordic countries. The symposium was prompted by a discussion in Denmark of the legal certainty of cases dealing with taxation. This discussion was based on three documents: a statistical analysis

Mats Tjernberg: Professor in Public Law, Tax Law, Lund University. E-mail: mats.tjernberg@jur.lu.se

$\star \star$ This article is part of a research project dealing with interpretation of tax law and the creation of precedents: Att döma skatt rätt-om principföljsam prejudikatbildning, which has received generous funding from the Ragnar and Torsten Söderbergs stiftelser of the percentage of cases found in favor of the taxpayer, presented by L. Hulgaard (2014), a response from President Dahl (2014) of the Danish Supreme Court (Højsteret), and a contribution that Pedersen (2014) had made to a conference on legal certainty in the previous March. Both L. Hulgaard and Pedersen claimed that it seemed to be difficult for a taxpayer in Denmark to succeed in cases about taxes and excise in the courts. Hulgaard's analysis was statistical, whereas Pedersen's was both statistical and qualitative. The symposium was arranged by Danske Skatteadvokater (Denmark's tax attorneys), in whose opinion there were grounds for taking Dahl seriously: The low percentage of cases found in favor of the taxpayer in the Danish Supreme Court required a closer study. Danske Skatteadvokater wanted the symposium to reveal, for instance, if structural differences in the way taxation cases were dealt with in the Nordic countries could provide an insight into the difficulty for Danish taxpayers to win in the tax situation. The participants in the symposium comprised Danish tax attorneys and researchers of tax law from Denmark, Sweden, and Norway. Olof Olsson, former Justice of the Finnish Supreme Administrative Court (Högsta förvaltningsdomstolen), represented Finland.

Both Sweden and Finland have a tradition of public administrative courts (in recent years, with some degree of specialization in taxation issues), whereas taxation cases in Denmark and Norway, like prosecutions and civil disputes, are heard in public general law courts. The Danish tax attorneys hoped, through the symposium, to persuade Danish politicians to consider other ways of organizing the authorities and law courts involved in taxation cases.

Taxation law can be viewed as unique for several reasons: the relationship between individual rights and the common good, the great complexity of the regulations and the continual amendments, and the substantial increase in international repercussions, for example. The statistical results presented in the Danish articles could be seen as an indication that judges are not always unbiased in their tax rulings.

It is my starting point for this article that judges should be seen as unbiased in handing down decisions 
and grounds in a way that does not favor one party. This starting point is self-evident. Lack of unbiasedness, however, does not imply the subjective intent to favor one of the parties. It is possible that lack of unbiasedness could exist because of the intuitive processes in decision making. Unbiasedness in legal decision making means that the legal interpretation is made unbiased. Yet because individuals make legal interpretations, it would seem that interpretation can never be truly unbiased (Brederode and Krever 2014). I adopt the view of Brederode and Krever, who characterize interpretation as intersubjective: "Interpretation is the subjective understanding of interpreter of the law, which in itself is unbiased. The purpose of legal interpretation is to arrive at legal decisions on the basis of a coherent argumentation using generally accepted normative premises. Interpretation is constitutive since it determines what valid law is."

My aim in the article is to provide an overall picture of the characteristics of rulings and proceedings related to taxation in these four Nordic countries ${ }^{1}$ and to discuss legal certainty in tax cases on the basis of some formal and substantive perspectives. Statistical studies of the outcome of taxation proceedings are, of course, interesting and thought provoking in enabling the detection of possible patterns and tendencies to one-sidedness. But the truth would probably be approached more closely and improvement better enabled through qualitative studies and discussions about the formal parameters for tax cases, and also by debating the substance of concrete rulings. In this article, I intend primarily to discuss the formal parameters and principles for rulings and judgments dealing with taxation, but also psychological processes of decision making.

This study addresses three major questions:

1. How can it be guaranteed that taxation authorities unbiasedly determine the amounts for which taxpayers are liable for tax or that they may deduct from their tax?

2. Is specialization in taxation issues in the courts desirable from the point of view of legal certainty?

3. And linked to the statistical studies presented at the symposium, are judges always unbiased? That judges should be autonomous and unbiased can probably be considered a self-evident proposition. It can probably also be assumed that all judges do, in fact, consider themselves, or at least must be expected to consider themselves, unbiased. But the major topic for discussion is twofold: Are judges in taxation cases really unbiased, and is it possible for them to maintain their unbiasedness at all times?

The comparison of the four Nordic countries benefits from the legal, cultural, and historical similarities of these countries and the fact that all four are civil law countries. Their tax legislations are extensive and, in some parts, highly detailed. The courts must, of course, play a role in interpreting both facts and law texts. It should be further noted that tax proceedings in Sweden and Finland are held in administrative courts-in contrast to in Denmark and Norway, where they are held in general courts. The choice is also a consequence of the countries represented at the symposium.

Although this article does not deal with tax law, as such, I am convinced that the discussions, even though some of them are made from national perspectives, can contribute to both the Nordic states' debate and the international debate.

\section{Taxation Proceedings in Sweden and Finland}

At an authority level, the burden of enquiry before a decision is made about taxation rests largely with the taxation authority, which must make a balanced appraisal of circumstances that speaks both in favor of and against the taxpayer. For a number of years, the Swedish Tax Agency has been the only central authority. In Finland, too, the authority is a unified one. In both countries, all authority decisions may be appealed to court by the taxpayers.

At the level of the law courts, Sweden lacks explicit regulations on the burden of enquiry in taxation cases. The burden of enquiry that normally applies is stipulated in the standard procedural regulations. ${ }^{2}$ As these cases involve two parties, the burden of enquiry rests with the parties. As a rule, the procedure is written. An official from the Swedish Tax Agency represents the state in the courts. There may be a risk that the lack of any genuine equality between the parties can affect the possibility of a complete enquiry. In the case of Sweden, especially for smaller taxpayers, this risk can be illustrated by comparing the resources and expertise available to the taxation authority, on the one hand, to the limited possibilities open to

28 § förvaltningsprocesslagen (1971:291) (Swed.). 
the taxpayer in receiving compensation through legal aid, ${ }^{3}$ on the other hand (see Lindkvist (2013)). The court of first instance is an administrative court (förvaltningsrätten), and the second instance is an administrative court of appeal (kammarrätten). The final instance in Sweden is the Supreme Administrative Court (Högsta förvaltningsdomstolen). The Swedish Supreme Administrative Court decides whether to issue an appeal permit. The court has a staff of about 90; its justices and the rest of the staff are divided into three preparatory units and an administrative unit. One of the units deals with preparation of all taxation cases. The justices' secretaries (lawyers who are legally qualified judges or other lawyers with relevant qualifications and backgrounds) have a primary task of preparing and reviewing the cases and presenting them with proposed decisions to the justices. The Swedish Supreme Administrative Court is divided into two departments that are equally empowered to deal with cases coming before the court. Specialization exists, therefore, at the preparatory level, but not when proceedings are being held. The court hears only 1-2 percent of the appeals submitted to it.

In Finland, taxation cases in the law courts are also regarded as disputes between two parties. The state is represented by the Tax Recipients' Legal Services Unit (Enheten för bevakning av skattetagarnas rätt), an independent unit within the Finnish Tax Administration. There are seven regional administrative courts divided into departments, one of which usually specializes in taxation hearings. Finland has no court of second instance comparable to the Swedish administrative courts of appeal. The Finnish Supreme Administrative Court (Högsta förvaltningsdomstolen) is the court of final appeal in taxation cases. The Finnish Supreme Administrative Court also requires an appeal permit and decides which cases it will review. Of the appeals, only 10-20 percent undergo substantive review (Olsson (2015)).

The Swedish Supreme Administrative Court is often seen to be adopting a formal style of interpretation, in which great importance is attached to the wording of the legislation, particularly if the wording is unambiguous. This situation also applies when interpretation results in a negative outcome for the taxpayer, compared to what would have been the result of a less formal interpretation (when wording in the travaux préparatoires would have benefited the taxpayer, for instance, but is contradicted by the wording of the legislation). This interpretive style is based on the strong position of the principle of legality. Interpretations of taxation legislation are not static, of

343 kap. 1 § skatteförfarandelagen (2011:1244) (Swed.). course, and different trends can be discerned from one period to another. Great weight was attached to the travaux préparatoires as a tool for the interpretation of Swedish law, until the 1990s, when it was followed by a more critical approach to contents that could be in conflict with unambiguous statutory wording (Tjernberg (2003)). In some cases, however, the Supreme Administrative Court has recently disregarded specific isolated wording in the legislation explicitly, in favor of a systematic interpretation that is closer to the spirit of the travaux préparatoires (see Rydin (2014); Tjernberg (2015). In Finland, great emphasis is also placed on the principle of legality, ${ }^{4}$ and, Olsson (2015) contends, interpretations of taxation legislation are characterized by formalism rather than by a more realistic style of interpretation. Ryynänen (2004), on the other hand, has suggested that there is some degree of balance between formalism and pragmatism.

In both Sweden and Finland, there are general statutory clauses prohibiting tax avoidance. The Finnish version has a somewhat broader application and can, unlike its Swedish counterpart, be invoked at the level of the taxation authority. The Finnish ${ }^{5}$ prohibition can be used to recategorize a fact (a loan as a gift, for instance), whereas the Swedish one ${ }^{6}$ is used to close gaps and loopholes in the wording of the legislation and invoke the intention of the law to create analogies to the regulations. The application of a legalistic style of interpretation by the courts can make tax planning possible also through the exploitation of gaps and loopholes in the legislation. This, in turn, creates the need for statutory methods of dealing with tax planning that conflict with the intention of the regulations. After all, a legalistic style of interpretation does not allow the prevention of undesirable tax planning by means of avoidance norms created by precedents-at least not in the same way as a less legalistic interpretation tradition does. The Swedish clause is used to establish analogies based on the intention of the legislation, but alongside the clause, the courts have developed a principle based on substance over form. ${ }^{7}$ This principle must not be applied, however, according to the Supreme Administrative Court, merely because the taxpayer's conduct has acquired a tax benefit (for a detailed discussion, see Burmeister (2012)).

In Sweden and Finland, both parties in tax cases are initially responsible for their own trial costs. Either party in a court hearing in Finland can, in principle, be awarded

\footnotetext{
$481 \S$ grundlagen (Finl.).

528 § lagen om beskattningsförfarande. (Finl.)

6 Lagen om skatteflykt (1995:575) (Swed.).

7 RÅ 2004 ref 27 (Swed).
} 
compensation for its trial costs; in Sweden, only the taxpayer can receive this compensation. ${ }^{8}$ The courts in both countries have been relatively reluctant to award taxpayers compensation for trial costs, and when they do, the amounts are low (for Sweden, see, for instance, Thorslund and Tärnqvist (2004)). Taxpayers in Finland would be ordered to compensate the state for its costs only if their claims were manifestly unfounded. It is extremely unusual for the state to be awarded trial costs (see Olsson (2015)).

\section{Taxation Proceedings in Denmark and Norway}

In taxation proceedings in Denmark and Norway, the burden of enquiry also rests with the authority, of course. In Denmark, the system for decisions in authorities is somewhat more complicated than it is in the other three countries: There is nothing to prevent appeal against a decision at the highest level of an authority to a court of law-even by the authority. A taxpayer can request legal review of issues only if they have been subject to appraisal at the highest level of the authority, landsskatteretten. The first instance of appeal against taxation decisions is the district court (byrett), ${ }^{9}$ which may, however, at the request of one or both parties, refer an issue to a high court (landsrett) as the first instance. ${ }^{10}$ This is possible when the issue involves a principle and is of general significance for the application and development of the law or has substantial social impact. If a case is referred to a high court as the first instance, its ruling can be appealed without restriction to the Supreme Court (Højesteret)-no appeal permit is required. The court can decide that two expert judges must participate in the hearing of a taxation case. ${ }^{11}$ Clearly, this rarely if ever happens. The reason for this was not elaborated at the symposium. Denmark has what is called a kammeradvokat (http://www.kammeradvokaten.dk/omos/), through a contract with a private law firm, to present the state's case in taxation hearings. The only country of the others that have something similar is Norway, as discussed in Section 5.3. In practice, the kammeradvokat has a monopoly over the pursuit of cases in the law courts on behalf of the state.

8 Lag om ersättning för kostnader i ärenden och mål om skatt, m.m. (1989:479) (Swed.).

9240 §, 2 st. retsplejeloven (Denm.).

$10226 \S$ retsplejeloven (Denm.).

$1120 \S$ retsplejeloven (Denm.).
Pedersen (2014) asserts that it is generally accepted in Denmark that judicial proceedings occur in the same way and with the same interpretative data as other public proceedings. Section 43 of Chapter 5 of Denmark's Grundlov does not prescribe more stringent legal support in case of taxation, which, Pedersen contends, many people wrongly misread it as doing. This stipulation on the lawfulness of taxation states that tax may be levied only by virtue of law without any general reference to the functional and administrative needs of the public agencies and without reference to the tax revenues needed by the state. Interpretation is based on the wording of the legislation, with the support of the travaux préparatoires. A particular problem arises with regard to transactions involving avoidance of the tax regulations. The courts in Denmark have adopted a standpoint that the formal situation in civil law is to be disregarded, whether it is lawful or not, if arrangements are in decisive conflict with their actual economic outcome. This reality norm means that in the absence of a statutory general clause, the courts have, as in Norway, created an instrument to deal with tax avoidance.

Norway has a system that resembles Denmark's (see Zimmer (2015b)). If a taxpayer is not satisfied with a decision from the taxation authority, appeal can be made to a tax appeal board (skatteklagenemnd), which may not include any member employed by the taxation authority. Two-thirds of the members of this board must have training and experience in accounting, law, or economics. Strictly no experience of taxation law per se is required. Zimmer adduces as a weakness the fact that preparatory work on the cases that come before the board is undertaken by the taxation authority-the instance that made the original decision. After a decision by the board, a taxpayer can approach the public court system. The law was changed in December 2014, so the regional tax appeal boards will be replaced as from July 1,2016 , by a national board, all members of which must have training in accounting, the law, or economics. Preparatory work on the cases that come before the board will be undertaken by its own secretariat, which is independent of the taxation authority. In courts of the first instance, tingrett, cases are decided by one judge and in the second court (lagmannsrett) by three judges. A department with five members usually decides cases in the Norwegian Supreme Court (Høyesterett). In the lower instances, if requested by one of the parties, the court may be supplemented by two lay judges. There is a tradition in Norway for the Supreme Court to provide a detailed and lengthy account of its findings. When a case comes before a court, it is primarily the Attorney General (Regjeringsadvokaten) who acts in very much the same way as the Danish Kammeradvokaten, 
who represents the state. Relatively, few tax cases come before the courts in Norway, presumably because considerable costs are entailed when cases are pursued in law courts. An appeal permit is required before the Supreme Court can hear a case. Only about 10 percent of the cases undergo actual review in the highest instance. As in the other countries, the principle of legality applies. Yet Norway, which has no statutory regulations against tax avoidance, has through the Supreme Court developed a practice of court intervention against tax avoidance. In other words, Norway lacks a statutory general clause prohibiting tax avoidance. Zimmer claims that the legislators are therefore obviously content with the development that has evolved through praxis. Zimmer has recently made some remarks, in my opinion of general interest, on the Norwegian, court created, antiavoidance doctrine. The starting point is, according to him, undoubtedly that civil law procedure should provide the basis for taxation (see Zimmer (2015a)). Zimmer, therefore, discusses whether an antiavoidance norm created through precedents is compatible with the principle of legality. The Supreme Court's precedents can be construed as showing that the court probably considers that the principle of legality addresses only the application of a rule of law. For this reason, the reclassification of a transaction in itself is not prevented by the principle. Zimmer doubts whether such a reclassification is correct, but nevertheless accepts the situation by pointing out that appraisal is made of the actual circumstances. I recognize this discussion from the Swedish debate on substance over form. A difference compared to the Swedish situation is that, the more a transaction lacks any intrinsic economic value apart from its taxation advantages, the greater the risk that the court in Norway will disregard it when appraising it for taxation purposes. Tax benefits are not enough in themselves, however. Some uncertainty seems to prevail about whether the degree to which the taxpayer intended to gain tax benefits should play a role. Originally it was stressed that the appraisal must concern circumstances from an unbiased point of view, but Zimmer (2014a) states that in recent years there has been a shift toward increasing the importance of the subjective aspects. The Telenor case ${ }^{12}$ has been significant for a more detailed determination of the avoidance norms. A basic requirement for application of the norm is that the main purpose of a transaction must be reduction of the tax. This is a necessary requirement, but not the only prerequisite for invoking the avoidance norm. The taxpayer's motives are also relevant in the overall appraisal that must be made.
Even though oral proceedings apply in Denmark, it was claimed at the symposium that the preparatory exchange of documents was of immense importance, as the outcome can be influenced already before the oral proceeding. Zimmer (2014b) asserts that things are slightly different in Norway. First, after the proceedings are finished, the judges confer about the outcome and the findings on which it is to be based with less constraint. In the deliberations among the judges, after the oral hearing, the presiding judge presents her, or his, view first, but in the voting, the presiding judge votes last.

Taxpayers who are successful against the state in Norway can be awarded compensation for their trial costs. At the authority level, these costs must have been substantial. The general rules about costs apply in court proceedings, the basic rule being that the losing party pays the other party's costs. One exception occurs when there would be no clarity about the issue in dispute, and there exist good grounds for having it heard by a court of law, irrespective of which party wins the case. If the taxpayer loses, he or she may very well have to pay the costs for the state. It can be extremely expensive for taxpayers to pursue taxation cases in Norway.

In Denmark, it is possible to be awarded trial costs in connection with an appeal against the decision of the Danish Customs and Tax Administration, SKAT. ${ }^{13}$ During the hearing, the winning party is awarded trial costs from the other party. Compensation between 50 and 100 percent may be obtained from the state, if the taxpayer gets approval to the main extent.

\section{Unbiasedness of the Taxation Authorities}

In Finland and Sweden, the governments exercise no control over the way taxation questions are dealt with by the authorities. There is some degree of cooperation with the government, however-at least in Sweden, where, when cases involving crucial questions of principle are lost, for example, new legislation is often initiated. Not infrequently, it begins at the authority level. The unification of the authorities means that there is firm central direction at authority level, which offers major advantages with uniform administrative routines, of course. There can be differences of opinion within the authority on difficult questions, but outwardly they present an appearance of una-

13 Skatteforvaltningslovens §§ 53-54. (Denm.). 
nimity. The Swedish Taxation Agency “must never initiate proceedings if it does not believe that they can be successful" (according to Inga-Lill Askersjö, formerly the authority's Chief Legal Officer and now a justice in the Supreme Administrative Court, cited in Krzymowska et al. (2015)). The Taxation Agency should, according to Askersjö, not view itself as merely one of the parties in a case. The authority's task is to safeguard state interests, but it is simultaneously required to enquire into questions, including circumstances and arguments, that speak on behalf of the taxpayer. This way of dealing with the questions applies even if the case lands up in a court of law (see Persson et al. (2013)). In Sweden, Höglund (2012) has discussed whether the self-evident formal demand for unbiasedness at authority level constitutes an unattainable ideal. Although there should, of course, be no scope for personal values, Höglund accepts relative unbiasedness, which means that some appraisals are, in different respects, incomplete. (I believe that Höglund doesn't want to exclude himself from the goal of absolute unbiasedness at the authority level.) In order to ensure the highest possible degree of impartiality at the level of the authority, Höglund has proposed the division of tax cases among various officials with specialized tasks. This specialization would probably, in Höglund's view, offer a greater depth of specialized expertise. Obviously, specialization does not automatically lead to unbiasedness, but competence may, of course, benefit the aim of unbiasedness. Höglund has also suggested that there should be a statutory right for the taxpayer to switch from one official to another at another taxation office.

In principle, all taxation cases coming before a court in Finland are first dealt with by a tax correction board (skatterättelsenämnden), which covers the entire country and is part of the taxation authority. The chair and members of this board must have a degree and be familiar with taxation, but no legal training is required. Each party bears its own costs.

In Denmark, taxation decisions are administered by SKAT (Told og- skatteforvaltningen), a unified authority, with powers covering the entire country. There has been a similar development in Norway, with a shift from municipal taxation offices to a national tax authority. The Norwegian Tax Directorate (Skattedirektoriatet) is responsible for the overall supervision and control of the individual tax offices and can give them both general instructions and instructions on specific questions. Zimmer (2015b) contends that the government made it clear in the 1970s that the Ministry of Finance (Finansdepartementet) could give instructions to the directorate on specific questions. Also in Denmark the Tax Ministry (Skatteministeriet) can issue instructions to the Taxation Authority-a privilege it seldom exercises. There is some degree of specialization in both countries, with certain issues being dealt with by specific offices. At the symposium, the representative of the Confederation of Danish Industry (Dansk Industri) said that he understood how the taxation authority could be testing and what rulings would be made when new untested situations arise. At the same time, the confederation did criticize the head of a department of SKAT who once declared that the authority was satisfied if it won 50 percent of its cases on transfer pricing.

The mission of a national taxation authority could be expressed as to ensure the funding of the public sector and contribute to the effective functioning of society for its citizens and commercial sector. The government directives issued to the Swedish Taxation Agency lay down that the tax and duty revenues desired are to be levied in a manner that is legally certain, cost effective, and simple for citizens and companies. Here we encounter the usual pair of concepts: legally certain and cost-effective. At the same time, taxes and duties are to be determined so that the difference between those levied and the theoretically correct amounts (the taxation gap) will be as small as possible. ${ }^{14}$ In all the Nordic countries, the initial decisions on taxation are made by the authority, and the starting point that applies is the principle of public office: that an enquiry will be made into all of the circumstances of significance for the decision. In fact, all the Nordic countries endeavor to provide uniformity in their administrations. In Sweden and Finland, in particular, key tasks are assigned to a national office or regional offices. In Sweden, although there is firm central direction, the Swedish Ministry of Finance exerts no control over the specific decisions made by the Swedish Taxation Agency. The Swedish constitution ${ }^{15}$ stipulates that neither the government nor parliament may determine how an administrative agency is to decide in a specific case on a matter concerning an individual that involves the exercise of official powers and is the application of law.

In December 2012, the ministry gave the Swedish Taxation Agency the task of surveying and assessing whether the authority was taking legal action correctly (see Skatteverket (2013)). Its survey showed that the authority had taken the correct legal action in 730 of its 760 cases ( 96 percent). Serious substantial shortcomings were found in 1.6 percent of the cases reviewed, and serious formal shortcomings in 1.8 percent, but serious errors were also found in 0.9 percent of tax penalties and 0.8 percent of evidence.

14 Fi 2013/2986 and Fi 2014/4482 (Swed.). 1512.2 regeringsformen (1974:152) (Swed). 
An assessment of all these shortcomings (39 shortcomings in the 30 cases in which litigation was considered incorrect) shows that 14 of them were substantial, 12 were formal matters, 7 concerned tax penalties, and 6 were deficiencies linked to the evidence. Among the cases in which an appeal court made a legal review of a material issue, the opinion of the authority was upheld totally in 75 percent, to some extent in 14 percent, and not at all in 11 percent. It should be noted that since the period covered by this evaluation, the Swedish Taxation Agency had taken legal action in some pilot cases involving major issues of principle or financial significance in which the courts have ruled against them. There is a definition of correct legal action, on which the method used in the survey was based. In the government's directive, correct legal action is defined as:

Correct legal action is when a case has been brought in accordance with the taxation authority's directives, guidelines and standpoints, when issues that are unclear have been checked with the legal department before action is taken, where decisions that are correct both substantially and formally have been made by the taxation authority and when the taxation authority has sufficient evidence for its litigation. ${ }^{16}$

According to the report, "checked with" also means that an official has come to an agreement with the legal department at the authority on initiating legal action in a court of law to procure a ruling on the legal situation. The definition was interpreted in the survey to mean that cases involving proceedings were to be included in the review, irrespective of who launched them-who literally "took action.” In other words, all the proceedings in which the authority was one of the parties were included.

Denmark is in a unique position, as judges are already involved at the authority level, in the National Tax Tribunal (landsskatteretten). During the symposium, the opinion was expressed that it was almost impossible to win an appeal to the next instance-a district court-if a judge had taken part in the treatment of the case in the National Tax Tribunal.

16 This and all other translations into English are my own.

\section{The Role of the Courts: Unbiasedness and Specialization}

\subsection{General}

Even if the task of a taxation authority is to make correct decisions on tax, one cannot exclude the possibility of there being a scope for the authority to test unclear issues of law or evidence. Once a taxation issue has left the authority level, however, it is undeniable that it comes before a court of law with the requirement that the "correct" decision will be made. Ryynänen (2004) contends that the court machinery provides the final guarantee that taxation is substantially correct. (For a general discussion of the unbiasedness of judges, see, for instance, Hart (1966).) The extent to which it is always possible to attain this level of unbiasedness is worthy of discussion (see, for instance, Dworkin (1997)) but a court must, of course, always endeavor to attain unbiasedness. It may be possible to discuss unbiasedness on the basis of statistical surveys, but mainly through the discussion of material questions and the way in which a court's arguments and findings are presented.

One key responsibility in this context rests with a Supreme Court when ruling on taxation cases: to create precedents and provide guidelines, for authorities and other courts, on the basis of which legal sources are to be ranked in interpreting taxation legislation. Sometimes clear legal propositions can be formulated, but there are usually complex issues relating to questions of fact and evidence; thus the circumstances in a particular case make it difficult to generalize rules of law from it. My starting point here is that it should be incumbent on all courts that has been asked to make a ruling to give an indication, directly or indirectly, of the method of interpretation it has used, making it easier for subordinate courts to make rulings in their turn. A Supreme Court must create precedents in questions of law. When it comes to the way rulings are reached, I agree with Kellgren (1997) that this issue should be governed largely by material and methodological rules. My point of departure is that a central requirement for the effective creation of precedents and compliance with them is the court's clear indication of the methodological rules and principles that have been applied in reaching a decision. If the court that is creating precedents accounts, for instance, for the premises on which it has followed supplementary sources to the legislation, it will then be easier for taxpayers and other courts to know how the Supreme Court values these sources. I support Kellgren's position and maintain that an incisive discussion focus- 
ing on principles is desirable. The Supreme Court should therefore account for the grounds and the principles on which its choice of interpretive arguments and options has been based. It should also express itself in terms of principles, without exaggerated caution or stress on the specificity of a case, thereby promoting the methodological continuity required if predictability and uniformity are to be obtained.

In Sweden, as in the other Nordic countries, it is clear that the Supreme Administrative Court is not primarily intended to "see that justice is done"; rather it is intended to provide those applying the law with guiding rulings. Even though there is no requirement to comply with precedents, great significance is attributed to the court's decisions. Not only its rulings, but also the grounds given for these rulings can play a critical role. The Supreme Administrative Court's critical task could be considered the creation of precedents. Gäverth (2009)) has perceived an increase in the number of case-specific rulings and senses frustration in the subordinate courts and litigants who are thereby deprived of adequate guidance from the Supreme Administrative Court. He has studied the reports from every case in every fifth year during the period 1975-2005 and has observed no change over time in the number of cases in which the court has written an explanatory statement. The proportion varies from 64 to 84 percent. There is a common belief in Sweden that only rulings from the highest instance contain the principle for the resolution of a legal issue that has value as precedents. The subordinate courts are expected to comply with the import of these rulings, as they do not want their decisions to be set aside if appealed. And hopefully also, to use the words of Sandström (1952, p. 273)), "in view of the uniformity that is desired in the application of the law." What is interesting and still of relevance is Sandström's discussion of how one can determine if a ruling really does contain a principle for the resolution of a legal issue. Sandström maintains that this should be apparent from the reasons given for the ruling. It is important, for the reasoning given, for a court decision to be as exhaustive and explicit as possible. Another quality aspect is that a ruling and the findings on which it is based should contribute to uniform interpretation of the law. As B. Hulgaard (1998) notes, judges need to be expert and highly ambitious. Lindell (2015) observes, however, that the professionalism of judges does not guarantee that every specific case will be judged correctly.

Despite the endeavor to attain rationality with regard to interpretation, the role played by unconscious processes or intuition can never be excluded nor can the impact of experience, common sense, and sound judgment. Modern research has shown that intuition is an au- tomatic or subconscious process (Betsch (2008); Kahneman (2011); Lindell (2015)), which occurs against a background of accumulated experience. Experience provides judgment that is not merely based on recollection and analysis of each specific factor; it can also, in parallel, be dealt with the intuitive (Lindell (2015)). Kahneman (2011) writes about parallel thought processes-one based immediately on intuition and the other on cognitive processes. Legal appraisals differ from others, in that a court always has specific facts before it on which to base its rulings (Lindell (2015)) - facts are often assessed intuitively but are deduced as intuitive appraisals become deductive. A court must justify its judgments and comply with the requirements of predictability and equality of treatment. According to Lindell, judging involves an automatic process that must be combined with an analytical appraisal. I claim, however, that there is a difference between accepting, on the one hand, that these factors can exist when decisions are made and maintaining, on the other hand, that they should be allowed to play a decisive role. There need not be any great difference-or perhaps no difference-between the results of the intuitive and the intellectual processes when a ruling is being decided upon. Experienced judges have, as Lindell (2015) notes, developed a large bank of expertise and experience that is used to enable rapid identification of the relevant issues and facts. The parallel thought processes may well lead to the same conclusion and probably do not take place in isolation. The significance of intuition in the legal system has also been discussed, for instance, by Andersson (2003); Gräns (2005), and Påhlsson (1998)), among others.

When it comes to factors as likelihood and fairness, apart from strict unbiased argumentation, they may not necessarily be excluded from legal interpretations based on principles. The grounds given for a decision (if such grounds exist) should in that case demonstrate awareness of factors as likelihood and fairness, and clarify them, thereby according greater transparency to the judgments and findings provided by the court of highest instance. Those applying the law must not be required to speculate if (and if so, in which situations) the Supreme Court has allowed these values to impact on outcomes (Påhlsson (2009)).

\subsection{Sweden and Finland}

No extensive statistical surveys of the proportion of granted appeals have yet been made in Sweden and Finland, although Nyquist and Fast (2007) have maintained that rulings in Sweden are made against the taxpayer 
in two-thirds of cases in courts of the first instance (see also Fast and Leidhammar (2003)). Sutela et al. (2014)) conducted an empirical analysis of judges' voting behavior in the Finnish Supreme Administrative Court in relation to their qualifications and gender. Linnankangas (2012) has also studied the voting behavior of judges in the Finnish Supreme Administrative Court. None of these Finnish studies did, however, measure the proportion of outcomes.

A great deal of energy has, in these two countries, been devoted to discussing the formal parameters for taxation cases. In Sweden, the official assessment is that increased specialization in dealing with taxation cases can contribute to greater legal certainty, better quality, and more efficient hearings. Increasing taxation specialization is also considered to play a decisive role in enabling a judge to manage proceedings more effectively. There has been an increase in taxation specialization in the two countries over time, which occurs within the courts. (For Sweden see Cedermark and Kristiansson (2015); SOU (2014, 76).) Specialization within the courts, which in Sweden's case is at the administrative courts (förvaltningsrätterna), means that taxation cases are heard by all the administrative courts but that they are allocated internally so that certain judges and other members of the staff are given a larger proportion of taxation cases than if those cases were allocated by ballot. Internal specialization within a court is instituted by assigning taxation cases to one or a few departments or divisions in the court, for instance, where they are prepared and decided by specific members of the staff. Further training in taxation law is also provided. It is difficult to assess the success of this specialization. In Sweden, it can be determined that the proportion of appeals that lead to some type of change in instances above the administrative courts (förvaltningsrätterna) has basically remained the same since the changes in the administrative court system. However, these statistics say nothing about in how many cases changes have been made. Where the quality of the rulings is concerned, a questionnaire survey revealed that most of the administrative courts believe that quality has improved (SOU $(2014,76)$ ). Specialization among judges in taxation cases should reasonably increase the likelihood of cases being judged with great expertise, compared to no existence of specialization, although this is difficult to establish statistically. The drawbacks that are normally noted are the risk of overly detailed specialization, which could lead to lack of judges if conflict of interest or absence due to illness occur, for instance. The Swedish enquiry also highlighted the risk of the judge losing general expertise and the risk that judges who specialize in taxation law become more restricted in their thinking and less ready to listen to all the shades of meaning in the arguments of the parties. It is essential, therefore, for a court with a goal of specializing to have an adequate number of judges with expertise in this field and a large number of cases (SOU $(2014,76)$ ). The proportion of tax cases at a court should be high enough for letting specialized judges dedicate most of their time to tax cases. The enquiry, therefore, proposed that there must be at least four taxation judges in a court of this type, and that at least 50 percent of the work of each of these judges should involve taxation cases. It is also proposed by the enquiry that the administrative courts of appeal (kammarrätterna) should introduce internal specialization. Today there is already a special department in the Swedish Supreme Administrative Court that deals with taxation cases.

The purpose of the rulings in the subordinate courts is virtually only to determine, and give grounds for, legal outcomes in concrete cases. Rulings in the highest instance are further expected to create compliance by providing precedents. In neither Finland nor Sweden is there any formal requirement to comply with precedents. The compliance that prevails in practice is probably due to tradition, faith in authority, the structure of the system of appeal, and the expectation that a court has ruled in accordance with a "correct" well-based unbiased conception of the law in force. To create compliance, in addition to justification of the specific outcome, the Supreme Court's rulings and reasoning should contribute to increased knowledge of "the law in force." This is not always the case. Referring to the difficulty, despite the high number of cases from the Supreme Court, of interpreting the Swedish general antiavoidance regulation (GAAR), for instance, Swedish practitioners sometimes claim orally that there is no point in intellectual appraisal on the basis of its application by the court, and that outcomes are far too dependent on which five justices happen to make the decision in a specific case about the GAAR (See Herman and Tjernberg 2011.) In my opinion, it is correct that rulings on the tax avoidance clause are case specific and often lack principle discussions, but I am doubtful about whether the outcome can clearly depend on which judges are making a ruling. (See the statistical analyses in Tjernberg and Herman 2011.)

\subsection{Denmark and Norway}

As noted, taxation cases in Denmark and Norway are dealt with by the general courts. It is perhaps natural, therefore, that questions have arisen about the appropriateness of this system. Taxation law is extensive, complex, and constantly subject to amendment. Danske Skattead- 
vokater considers it a major social problem that taxpayers so rarely win cases. The expenses associated with legal proceedings, combined with the poor odds for success, could mean that many taxpayers abandon the idea of pursuing their issue in court. As Pedersen (2014) notes, the number of successful appeals should be zero in an ideal world, an indication that the way the taxation authorities make decisions is always correct, both formally and in substance. But, he contends, that view would be unrealistic. The number of successful appeals may be low because the decisions made by the taxation authorities are largely correct; it may indicate that even at the level of the authority, there is great legal certainty. But, Pedersen suggests a small proportion of successful appeals may also be a result of a procedural system that overserves the needs of one party-in this case the state-and that it is hazardous to draw conclusions based solely on statistics. Rather, a jurisprudential study of rulings can be based on decisions and the grounds provided. Undertaking this type of analysis of all the judgments that may be included in extensive statistical data would be an extremely comprehensive endeavor. Rather, Pedersen has discussed a selection of Danish rulings, which, he believes, contain surprising outcomes. In his selection, Pedersen believes that he can see that in situations in which there is doubt about factual or legal circumstances, the case is decided in favor of the state. The question of establishing administrative courts has been discussed and studied extensively in Denmark. The short version is that administrative courts have not been established because of a traditional reluctance to weaken the status of the regular courts. ${ }^{17}$ The Danish Constitution does not currently allow the establishment of a Supreme Administrative Court other than Højesteret. It would be possible, however, to establish administrative courts at a lower level. After enquiring into the issue, Retsplejerådet decided not to submit proposals to establish independent administrative tribunals, as it would not be considered an improvement over the way the general courts are already dealing with administrative cases. The investigation found, as well, that such a move would require significant resources for the courts.

For the contrary opinion, see Andersen (1999), who has argued in favor of administrative courts in Denmark. According to Andersen, administrative cases are often burdensome, time-consuming, and costly. In addition, they constitute such a small portion of the total judiciary domain that courts could hardly be argued to have specific

17 Retsplejerådets betaenkning 1401/2001 om reform af den civile retspleje, s. 142 (Denm.). administrative law expertise. Andersen also argues that the administrative courts would subordinate to the offcialprincip; use a writing-oriented procedure; and operate smoother, faster, and in a less costly manner for the individual. Retsplejerådet did not share Andersen's analysis, and argued instead that administrative cases constitute a large and increasing proportion of court cases. In principle, Retsplejerådet meant that Denmark, together with Norway, among others, has judicial control over the administration, which is radically different from countries with administrative courts. In Denmark, courts are used to handling general legal rules and principles of particular importance, but also, if necessary, to interpret more specific administrative rules. According to Retsplejerådet, some type of specialization would be appropriate, but should, in that case, be made internally at the individual courts. ${ }^{18}$ Retsplejerådet thereby found it essential that all court judges retain a generalist role, which could be combined with delegation to a certain department or certain judges in order to achieve particular specialist knowledge in a certain area. It appears to be the current Danish opinion that a combination of roles-the generalist and the specialist-helps judges to achieve sufficient qualifications. A high level of specialization could lead judges to lose the sense of general legal principles and rules. On the other hand, Retsplejerådet acknowledges that there are a number of case types in which it is appropriate and necessary that judges have some specialized knowledge. But the work should be done internally in the individual courts.

In Norway, too, there are discussions about whether the rulings of the Supreme Court are too favorable for the state. Zimmer (2015a) has conducted a study of the rulings of the court in the field of income and wealth tax between 1997 and 2012. He included 124 rulings, of which 57.3 percent were in favor of the state, 39.5 percent in favor of the taxpayer, and 3.2 percent divided. Zimmer discusses conceivable explanations: that only doubtful cases can obtain appeal permits, for instance, and that those in which the taxpayer has no prospects of success are not heard by the court. Zimmer has also examined the frequency of dissenting opinions.

The most interesting observation is that there are great differences among judges in the party they tend to favor in reaching their judgments. One justice had found in favor of the taxpayer in 62.9 percent of rulings and another in only 18.2 percent. For most of them, this figure was below 50 percent. Zimmer does not consider that there are any

18 Betænkning No. 1398/2001 fra Domstolenes strukturutredning, p. 223-224. (Denm.). 
grounds for believing that an allocation of cases by ballot leads to the major differences, but rather that it cannot be discounted that the justices' professional background plays a role. Justices with university backgrounds tend to be more favorable to the taxpayers, and those who come from positions in the Ministry of Justice are more likely to favor the state. Zimmer is extremely cautious in his conclusions, but claims that there is "no inconsiderable risk" that the composition of the court ( 5 justices in each case from a total of 20) may have a bearing on the outcome of a specific case.

\section{Concluding Remarks}

In my opinion, it is fairly clear that Sweden and Finland, on the one hand, and Denmark and Norway, on the other hand, offer somewhat disparate approaches in ensuring the legal certainty in taxation cases. These differences should not be exaggerated, as all four countries are part of the Nordic legal tradition. Because of their mutually comprehensible languages, jurisprudential discussions of taxation law are disseminated and make an impact in all four of the countries dealt with here, which naturally applies to issues relating to taxation and legal certainty.

My aim in this article has been to help stimulate debate on how legal certainty in taxation should be ensured and the way it is discussed in the Nordic countries. I would also like to extend this debate to English-speaking researchers and practitioners in taxation law. My desire is to offer my view of how the organization of the authorities and the law courts can help to enhance legal certainty in taxation decisions and proceedings.

Taxation poses special challenges. From the point of view of society, it is vital for there to be an effective tax administration, and particularly important that a high degree of competence and unbiasedness be the ultimate goal in the courts. Unified tax administration enhances legal certainty and equality of treatment. At the authority level, levying the correct tax is another absolute goal, and a tax authority must make tax decisions in accordance with lege lata. In Sweden and Finland, specialization in dealing with taxation cases has been considered justifiable at the level of the courts, and Swedish studies have addressed this issue in recent years. The aim of specialization is to enhance legal certainty and raise quality. An additional argument for specialization is maintaining of expertise in the multifaceted area of taxation law. In both countries, specialization within the general administrative courts has been chosen rather than the establishment of specialized courts. In the Swedish court system at least, judges are offered continuing professional development in taxation law. Specialization has recently been proposed in Sweden in also the administrative courts of appeal as well as the administrative courts. In view of the limited number of cases granted permits to appeal in the Supreme Administrative Court further, the administrative courts of appeal often function in practice as the highest court of appeal, and therefore a development of this kind should be viewed positively from the perspective of legal certainty.

Legal authorizes in all four countries seem to be convinced that the court model they have chosen is the most appropriate. Traditions seem to be important, and the anticipated challenges following from a change of system may weigh more heavily than unsure improvements do. It is my impression, however, that Norway and Denmark could learn from the other two countries. Even though it is difficult, or impossible, to measure and compare degrees of legal certainty between specialist and generalist judges in deciding on specialization or generalization, a state's choice could send essential signals to the stakeholders. Modern tax law is as complicated as ever, and expertise in tax law should raise the possibility of getting the "right" judgments. An argument for general courts is that quality of judgments benefits by knowledge of more general legal principles. Maybe the way the Swedish Supreme Administrative Court is organized could serve as an appropriate model: the preparatory work is made by specialists, but the judges decide not only in tax cases, but in all types of cases that come for the court.

In view of the significant role played by taxation for both the state and the individual, the additional costs that may be entailed in introducing and working with specialization must be viewed as justifiable. There is little meaning in contrasting general law courts to administrative courts in these discussions. No hierarchical conflict between the two systems is shown in Sweden.

Most people can probably agree that the administration of the law should endeavor as far as possible to be unbiased and devoid of value judgments. I believe that one must accept the fact that this is not always the face of reality and that values and preconceptions do, in fact, influence both research and administration of the law, desirable or not. Further along that line, is the question of whether it is acceptable that a judge not always adopt an unbiased approach in making judgments? The answer to this question is "no." Judgments must, of course, be made unbiased, and it is self-evident that all judges believe that they always endeavor to judge issues correctly rather than considering which party is going to win the case. But toocategorical assertions of this self-image impede discussion 
of the process of making judgments and legal certainty. Raising awareness of the processes involved in judging can increase the stringency of argumentation, grounds, and conclusions in a judicial decision, to the benefit of legal certainty.

\section{References}

Andersen, Jon. 1999. ”Domstolskontrol trænger til fornyelse.” Lov \& Ret (8).

Andersson, Håkan. 2003. “Likhetsargumentation-Analogi och Metamorfos.” In Festskrift till Åke Frändberg, edited by Anders Fogelklou and Torben Spaak, 13-37. Uppsala, Sweden: Iustus.

Bernitz, Ulf and Jane Reichel. 2015. “Effektivitet eller Legitimitet? En Bedömning av Skatteverkets Nya Samarbetsformer, s.k. Fördjupad Dialog." Skattenytt: 508-24.

Betsch, Tillman. 2008. "The Nature of Intuition and its Neglect in Research on Judgment and Decision Making. In Henning Plessner, Cornelia Betsch and Tillman Betsch. Intuition in Judgment and Decision Making. New York, USA: Taylor \& Francis Group L.L.C.

Burmeister, Jari. 2012. Verklig Innebörd. En Studie av Inkomstskattepraxis. Stockholm: Norstedts juridik.

Cedermark, Pia and Hanna Kristiansson. 2015. "Förbättrad Hantering av Skattemål i de Allmänna Förvaltningsdomstolarna.” Skattenytt: 125-33.

Dahl, Börge. 2014. “Dommerne Holder sig til Loven-en Kommentar til Advokat Lida Hulgaards Undersøgelse af Dommeres Vota I Skattesager." Tidsskrift for Skatter og Afgifter (185).

Dworkin, Ronald. 1997. Taking Rights Seriously. New York: Bloomsbury Academic.

Fast, Katarina and Börje Leidhammar. 2003. "Rättssäkerhet och Effektivitet-en Omöjlig Kombination i den Svenska Skatteprocessen?" Svenskt Näringsliv.

Finansdepartementet. Fi 2013/2986 and Fi 2014/4482. “Regleringsbrev för Budgetåret 2015 Avseende Skatteverket.”

Gräns, Minna. 2005. "Some Aspects of Legal Decision Making in the Light of Cognitive Consistency Theories.” Perspectives on Jurisprudence. Essays in Honor of Jes Bjarup. Scandinavian Studies in Law (48): 99-122.

Gräns, Minna. 2013. Decisio Juris. Uppsala, Sweden: Iustus.

Gäverth, Leif. 2009. “Regeringsrättens Prejudikatroll Sedd Genom Kristallkulan.” In Regeringsrätten 100 år, edited by Sren Hecksher, Anna-Karin Lundin, Carl Gustav Fernlund, Kristina Ståhl, Annica Runsten and Christina Weding, 165-73. Uppsala, Sweden: lustus.

Hart, Herbert Lionel Adolphus. 2012. The Concept of Law ( $3^{\text {rd }}$ edition). Oxford: Oxford University Press.

Hulgaard, Bodil. 1998. “Några Tankar om Rättssäkerhet.” Svensk Skattetidning: 777-84.

Hulgaard, Lida. 2014. “Dommeres Vota i Skattesager 2002-2011-En Statistisk Undersøgelse.” Tidsskrft for Skatter og Afgifter (132).

Höglund, Mats. 2012. "Ska Skatteverket Vara Opartiskt i Skatteärenden?” Skattenytt: 29-42.

Kahneman, Daniel. 2011. Thinking Fast and Slow. New York. Farrar, Straus and Giroux.

Kammeradvokaten. 2015. http://www.kammeradvokaten.dk/omos/. Accessed 19 October 2015.
Kellgren, Jan. 1997. Mål och Metoder vid Tolkning av Skattelag. Uppsala, Sweden: lustus.

Krzymowska, Adriana, Ingrid Melbi, and Roger Persson Österman. 2015. “Intervju med Inga-Lill Askersjö.” Skattenytt: 503-7.

Lindell, Bengt. 2015. Helhetsbedömningar och Intresseavvägningar: en Introduktion till Användningen av Multikriterieanalys och Oskarp Logik i En Juridisk Kontext. Uppsala, Sweden: Iustus.

Lindkvist, Gustav. 2013. "En Mer Ändamålsenlig Förvaltningsprocess-Några Kommentarer Angående Skattemål.” Skattenytt: 264-70.

Linnankangas, Esko. 2012. “Täydellisen Verohallintotuomarin Taustat ja Ominaisuudet." Vesto: 249-54.

Nyquist, Kerstin, and Katarina Fast. 2007. "Specialisering $i$ Skattemål-för Bättre Rättssäkerhet och Effektivitet i Skatteprocessen." Skattenytt: 19-25.

Olsson, Olof. 2015. "Finländsk Nationalrapport till det Nordiska Arbetssymposiet om Prövning av Skatteärenden ur Rättssäkerhetsperspektiv i Århus 6-7.3 2015."

Pedersen, Jan. 2014. "Domstolsprøvelse af SkattesagerRetssikkerhed, Statistik og Retsanvendelse.” Ugeskrift for Redsvidenskab. Forvaltningsret 1.5 Skatter 7.4 (U.2014B.251).

Persson Österman, Roger, Ingrid Melbi, and Adriana Krzymowska. 2013. “Intervju med Inga-Lill Askersjö." Skattenytt: 232-7.

Påhlsson, Robert. 1998. "Intuition och Rättfärdigande i Skatterätten." Skattenytt: 445-53.

Påhlsson, Robert. 2009. "Kritiska Rättsfallsstudier-Exemplet väsentlig anknytning." In Regeringsrätten 100 år, edited by Sren Hecksher, Anna-Karin Lundin, Carl Gustav Fernlund, Kristina Ståhl, Annica Runsten and Christina Weding 415-25. Uppsala, Sweden: lustus.

Rydin, Urban. 2014. "Ytterligare Några Ord om HFD:s Lagtolkning." Skattenytt: 25-41.

Ryynänen, Olli. 2004. “Uppslag till Förbättring av den Skattskyldiges Rättssäkerhet.” JFT: 636-9.

Sandström, K.G.A. 1952. “Om Skattelagars Tolkning och Tillämpning." Svensk skattetidning: 241-76.

Skatteverket. 2013. "Rättsavdelningens Genomgång av Myndighetens Processer i Domstol, 2013-12-18."

SOU 2014:76. "Fortsatt Utveckling av Förvaltningsprocess och Specialisering för Skattemål."

Sutela, Mika, Veijo Tarukannel, and Matti Tolvanen. 2014. “Ennakkopäätökset Ja Änestäminen: empiirinen analyysi tuomareiden eriävien mielipiteiden esittämisestä korkeimmassa hallintooikeudessa." Lakimies (5): 719-35.

Tjernberg, Mats. 2003. "Regeringsrättens Strikta Lagtolkning." Skattenytt: 14-22.

Tjernberg, Mats. 2015. “Intressant Tolkningsavgörande Från HFD om Uttagsbeskattning vid Indirekt Ägande i Överlåtande Handelsbolag." Skattenytt: 745-50.

Thorslund, Gunilla and Lars Tärnqvist. 2004. "Ersättning i Mål och Ärenden om Skatt." Skattenytt: 545-56.

Zimmer, Frederik. 2015a. "Høyesterett og Skatteretten." In Lov Sannhet Rett. Norges Høyesterett 200 år, edited by Tore Schei, Jens Edvin A. Skoghøy and Toril M. Øie, 694 ff. Oslo, Norway.

Zimmer, Frederik. 2015b. "Prøvelse av Skattesaker ut fra Rettssikkerhetsperspektiv-Norge.” Nordiska Arbetssymposiet om Prövning av Skatteärenden ur Rättssäkerhetsperspektiv $\mathrm{i}$ Århus 6-7 March 2015. 